\title{
Tensile Strength and Density of Teki Grass (Cyperus Rotundus) Used as Materials for Fibre Composites with Fibre Angle Variation
}

\author{
Muhammad Rafiq Yanhar $^{1}$ A. Haris Nasution ${ }^{2}$ \\ ${ }^{1,2}$ Department of Mechanical Engineering Faculty of Engineering Islamic University of North Sumatera \\ (Indonesia)
}

\begin{abstract}
The primary purpose of this study is to determine the tensile strength and density) of the Indonesian term teki grass (Cyperus rotundus) in which this teki grass is used as the reinforcement materials for the production of fibre composite. The production process is carried out by using varieties of fiber directions ranging from $0^{\circ}, 45^{\circ}, 90^{\circ}$, and random.The methods in use is hand lay-up with 3 repetitions. Teki grass is chosen because it is easily found and has the following significances: biodegradable, harmless to health, available in nature in large quantities, and cost-efficient. Another reason because this plant is also an agricultural weed that is difficult to eradicate, not fully utilized, and often found in open field. While a matrix for fiber binder selected from epoxy resin material. From the test results it can be concluded that the variations in the direction of fibers effect on the tensile strenght of the composite. Average tensile strength of specimens with fibre directions of $0^{\circ}$, $45^{\circ}, 90^{\circ}$, and random are $15.60 \mathrm{MPa}, 18,69 \mathrm{MPa}, 30.11 \mathrm{MPa}$, and $22.79 \mathrm{MPa}$. In contrast, variations of fibre directions do not affect the density.
\end{abstract}

Keywords: Tensile strength, density, composite, hand lay up, fiber direction

\section{Introduction}

Until now, industries remainto use synthetic fibre as their composite reinforcement materials. Synthetic fibreis especially employed in the manufacturing industries of various products such as aircraft, boat hulls, wind turbine blades, car body, among others (Corning, 2010). Of various types of fibre, synthetic fibre glass is the most widely used. In 2009 the consumption of fibre glass around the world has reached 4 to 5 million tons per year and is expected in 2017 to reach 8.5 million tons per year (Composite World, 2009).

Uncluckily the fibre glass has some negative impacts, such as, it requires high cost, can not be naturally decomposed, consists of limited number, and is harmful to health (Yudo, 2010). Moreover, fibre glass can increase the risk of lung cancer. Since the size of fibre glass is varied, the small particles of this fibre, which are of course not seen with naked eyes, will be inhaled if mouth is not covered by masker and runs into the blood; meanwhile, the larger particles can cause irritation to skin, eyes, nose and throat.Therefore, researchers have currently attempted to find an alternativeby replacingthe synthetic fibrewith natural fibre which has several advantages, for example, it is easily discovered, biodegradable, harmless to health, large availability in nature in large, and low cost (Yudo, 2010).

In this study the natural fibrerefers to any fibre which is manufactured fromteki grass (Cyperus rotundus). This type of fibreis brought into research since the teki grass becomes the agricultural plants which are not fully utilized and are often found in the open fields. The teki grass is very adaptive and therefore it consists of weeds that are very difficult to eradicate. It has tubers which are capable of reaching one meter in depth so the such tubers are saved from tillage $(30 \mathrm{~cm})$. This grass is discovered all over the world, grows well when sufficient water is available, toleranttowards inundation, and able to withstand in drought conditions (Wikipedia, 2015). In addition, the matrix for binding the fibre is the epoxy resin.

\subsection{Equipments and Materials}

\section{Research Methods}

During this research there are some equipments and materials involved, such as, specimen mold with the same size assuggested by ASTM D638 - 02a, a tensile testing machine servopulser, epoxy resin and its hardener, fibre teki (Cyperus rotundus), wax, glass coatings, gloves, measuring cups, scissors, digital scales, clippers, and other supporting equipments. 


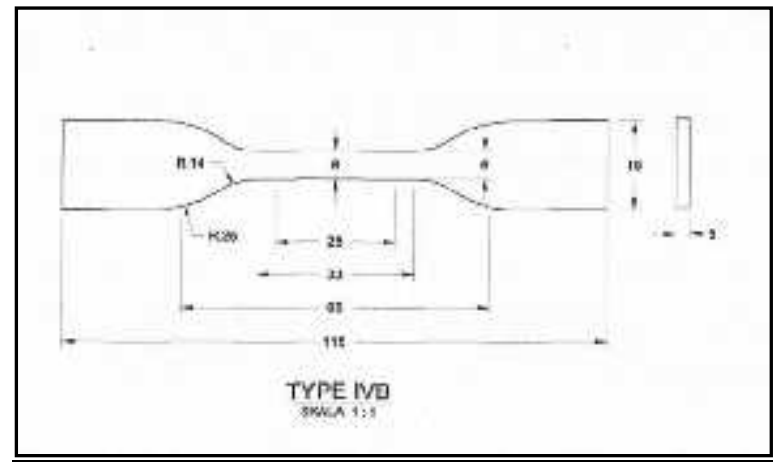

Figure 1. Tensile test specimens of ASTM D638 - 02a

\subsection{Research Stages}

1. The teki grass is pull out from the ground, cleaned with water, soaked for one hour in the 5\% solution of $\mathrm{NaOH}$ to remove the sap (lignin) and the impurities that can reduce the bond quality between the matrix and the fibre.

2. Drying the teki in the shiny sun for 5 days would remove its liquid.

3. After the teki is dried, it is weighed and cut into the desired size as determined in the manufacture of the specimen.

4. The metal mold is smeared with wax to make easy to remove the spicemen from the mold when it becomes hardened. Glass is placed in the bottom part of the mold and is coated also smeared with wax.

5. The ratio of epoxy resin and the hardener is in the range of 1:1 which is then stirred completely and this mixture is poured into the mold.

6. The fibreof teki grass is laid down on the specimen in the fibre directions of $0^{\circ}, 45^{\circ}, 90^{\circ}$, and random.

7. Then the epoxy resin is poured on the surface of the fibre.

8. Once the mixture begins to thicken, the resin and the glass fiber are placed on the top of the mold and pressed with ballast to eliminate the voids (air bubbles) which are trapped and to flatten the surface of the specimen.

9. Allow the specimen to become hardened for 12 hours; open the mold after 12 hours and the specimen is completely formed and ready for strength test.

10. The same stages are carried out make specimen density.

\subsection{Tensile Test}

\section{Results and Discussion}

After the specimens are removed from the mold, the next step is to hold tensile test in which each composition is carried out three times. The test results of tensile strength of composite specimens can be seen in the Table 1 below:

Table 1. Composite Tensile Strength

\begin{tabular}{|c|c|c|c|c|}
\hline No. & Fibre Angle & Specimen (n) & Tensile Strength (MPa) & Average Tensile Strength (MPa) \\
\hline \multirow{3}{*}{1.} & \multirow{3}{*}{ 0o } & Specimen 1 & 15,4 & \multirow{3}{*}{ (n) } \\
\hline & & Specimen 2 & 17,1 & \\
\hline & & Specimen 3 & 14,3 & \\
\hline \multirow{3}{*}{2.} & \multirow{3}{*}{450} & Specimen 1 & 18,4 & \multirow{3}{*}{18,69} \\
\hline & & Specimen 2 & 18,89 & \\
\hline & & Specimen 3 & 18,77 & \\
\hline \multirow{3}{*}{3.} & \multirow{3}{*}{$90 \mathrm{o}$} & Specimen 1 & 30,4 & \multirow{3}{*}{30,11} \\
\hline & & Specimen 2 & 28,33 & \\
\hline & & Specimen 3 & 31,6 & \\
\hline \multirow{3}{*}{4.} & \multirow{3}{*}{ Random } & Specimen 1 & 22 & \multirow{3}{*}{22,79} \\
\hline & & Specimen 2 & 24,7 & \\
\hline & & Specimen 3 & 21,66 & \\
\hline
\end{tabular}




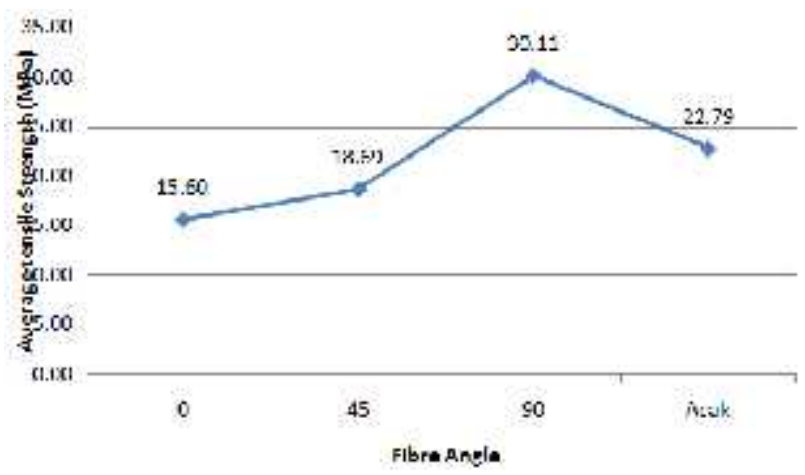

Table 1 illustrates that the average of fibre tensile strength within the direction of $0^{\circ}$ (transverse) is indicated by 15,60 MPa and this shows the lowest level. When the direction is in the $45^{\circ}$ the average strength sits in the 18,69 MPa. The highest average of tensile strength in the direction of $90^{\circ}$ (longitudinal) reaches 30,11 $\mathrm{MPa}$ and this tensile force is in line with the machine. In contrast, in the random direction the average tensile strength shows a significant point of 22,79 MP.

The average tensile strength of the fibre in the direction of $0^{\circ}$ (transverse) is indicated as the lowest point since this direction has the biggest angles with the most major tensile force equals to $90^{\circ}$. When the fibre direction shows $90^{\circ}$ (longitudinal), this direction is in line with the tensile strength and as a result, this directiondemonstrates the biggest average of tensile strength.

Fibres in the directions of $45^{\circ}$ have greater average of tensile strength than of $0^{\circ}$ since this direction forms an angle of $45^{\circ}$ compared to the tensile force. Meanwhile, the average tensile strength of random fibreis proved to be above the fibre of angle $45^{\circ}$ because the direction of free fibre spreads in all directions and it has formed angles ranging between $45^{\circ}$ and $90^{\circ}$.

\subsection{Density Test}

Soon after the specimens are removed from the mold, the following step is to carry out density testin which each composition is carried out three times. During density test, the fibre mass which is used in this composition should be in uniform, namely, 2 grams in weight.Therefore, the measurement of density is based on one of the compositions because the variations in fibre direction does not influence the composite density.

Table 2. Composite density

\begin{tabular}{|l|l|l|l|l|l|l|}
\hline No. & Fibre Direction Variable & Specimen $(\mathrm{n})$ & Mass $(\mathrm{gr})$ & Volume $(\mathrm{cm} 3)$ & Density $(\mathrm{gr} / \mathrm{cm} 3)$ & Average Density $(\mathrm{gr} / \mathrm{cm} 3)$ \\
\hline \multirow{3}{*}{1} & \multirow{3}{*}{450} & Specimen 1 & 11,88 & 8 & \multirow{2}{*}{1,485} \\
\cline { 3 - 7 } & & Specimen 2 & 11,71 & 8 & 1,463 & \multirow{2}{*}{} \\
\cline { 3 - 7 } & & Specimen 3 & 12,24 & 8 & 1,53 & \\
\hline
\end{tabular}

The results of the polyester resin matrix test demonstrate that the lowest average of density is 1,472 $\mathrm{gr} / \mathrm{cm} 3$; meanwhile, the fibre length variable and the fibre density average posit the value of $1.679 \mathrm{gr} / \mathrm{cm} 3$ with the fibre weight of 4 grams.

\section{Conclusion}

1. Variation of directions influence the composite tensile strength.

2. Fibres with direction of $0^{\circ}$ have the lowest tensile strength, namely, 15,60 MPa because this direction consists of the biggest angle $\left(90^{\circ}\right)$ from the tensile testing machine. While the tensile strength of the fibre in the direction of $45^{\circ}$ is the second lowest of about $18,69 \mathrm{Mpa}$ since this direction forms an angle $45 \mathrm{o}$ compared to the direction of tensile force produced by tensile testing machine.

3. The highest tensile strength is $30,11 \mathrm{MPa}$ and falls on the fibre with the direction of $90^{\circ}$ since this direction is in the elevance with the tensile force of tensile testing machine.

4. The second largest tensile strength is $22,79 \mathrm{Mpa}$ and is found on the of random fibre because the directions of free fibres direction are spread in all directions and these directions have formed the angles between $45^{\circ}$ and $90^{\circ}$ (approaching the direction tensile force of tensile testing machine).

5. The variations of fibre directionsdo not bring any impacts on the composite density since in this case the fibre mass is proved to influence. 


\section{Bibliography}

[1] Astuti, 2013, Pengaruh Ketebalan Serat Pelepah Pisang Kepok (Musa Paradisiaca) Terhadap Sifat Mekanik Material Komposit Poliester Serat Alam. Jurnal Ilmiah.

[2] ASTM, “Annual Book of ASTM Standard” West Conshohocken, 2002.

[3] Composites World, 2009, The making of glass fiber, CompositesWorld.htm

[4] Diharjo K. dan Nuri S.H., 2006, Studi Sifat Tarik Bahan Komposit Berpenguat Serat Rami Dengan Matrik Unsaturated Poliester, Proseding, Seminar Nasional Teknik Mesin FT Univ. Petra-Surabaya..

[5] Hartono Yudo, 2010, Analisa Teknis Rekayasa Serat Enceng Gondok Sebagai Bahan Pembuatan Komposit Ditinjau dari kekuatan tarik, Jurnal Ilmiah.

[6] Hadi, B.K, 2000,Mekanika Struktur Komposit, Direktorat Jendral Pendidikan Tinggi

[7] Nasmi Herlina S dkk, 2011, Pengaruh Panjang Serat Dan Fraksi Volume Serat PelepahKelapa Terhadap Ketangguhan Impact Komposit Polyester, Jurnal Univ Mataram ,.

[8] Owens Corning, 2010, Top Ten Composite Apps.

[9] Pendi Silalahi, 2008, Kinerja Komposit berbahan dasar serat Pisang Abacca dan Resin Epoksi Dengan Keramik Untuk Rompi Tahan Peluru, Tesis, Dept. Teknik Kimia Universitas Indonesia.

[10] Paryanto, dkk, 2010, Pengaruh Orientasi Dan Fraksi Volume Serat Daun Nanas (Ananas Comocus) Terhadap Kekuatan Tarik Komposit Resin Polyester Tak Jenuh (UP), Jurnal Ilmiah. 